\title{
FORAGE PRODUCTION AND PRESERVATION OF SPECIES BY ENRICHING CAATINGA WITH GRASSES AND THINNING AREAS INTO STRIPS ${ }^{1}$
}

\author{
JEFTE ARNON DE ALMEIDA CONRADO ${ }^{2 *}$, ANA CLARA RODRIGUES CAVALCANTE ${ }^{3}$, RAFAEL GONÇALVES \\ TONUCCI ${ }^{3}$, MARIA SOCORRO DE SOUZA CARNEIRO ${ }^{2}$, MAGNO JOSÉ DUARTE CÂNDIDO ${ }^{2}$
}

\begin{abstract}
The objective of this study was to evaluate the thinning into strips and the enrichment with exotic grasses in a Caatinga area in order to maintain and increase the biodiversity of native vegetable species and forage production. Two studies were carried out - one in an area of Caatinga thinned into strips and one in an unmanipulated Caatinga area — during the rainy and rainy-dry season transition periods in 2016. The production of herbaceous biomass was evaluated, and the diversity and equability of the two areas were assessed through Shannon-Weaver (H') and Pielou (J') indexes. The establishment of massai and buffel grasses at the center and edges of the area thinned into strips was also evaluated. During the rainy season, the production of herbaceous biomass in the area thinned into strips and the unmanipulated area was $1,228 \mathrm{~kg} \mathrm{ha}^{-1}$ and $833.33 \mathrm{~kg} \mathrm{ha}{ }^{-1}$, while during the rainy-dry transition period, it was $1,973 \mathrm{~kg} \mathrm{ha}^{-1}$ and $836.00 \mathrm{~kg} \mathrm{ha}^{-1}$, respectively. The indexes remained similar: H' (1.86) and J' (0.74) for the area thinned into strips, and H' (1.77) and J' (0.85) for the unmanipulated area. The massai grass presented better establishment and development than that by the buffel grass in the center and edges of the area thinned into strips. Thus, thinning into strips increases the biodiversity of an area, and this combined with enrichment through grasses increases the biomass of herbaceous forage.
\end{abstract}

Keywords: Botanical composition. Massai grass. Buffel grass. Shading. Full sun exposure.

\section{PRODUÇÃO DE FORRAGEM E PRESERVAÇÃO DE ESPÉCIES DA CAATINGA ENRIQUECIDA COM GRAMÍNEAS E RALEADA EM FAIXAS}

\begin{abstract}
RESUMO - O objetivo deste estudo foi avaliar o raleamento em faixas e o enriquecimento com gramíneas exóticas em uma área de Caatinga, de modo que fosse possível manter e ou aumentar a biodiversidade de espécies vegetais nativas, e intensificar a produção de biomassa de forragem. Dois estudos foram conduzidos em uma área de Caatinga raleada em faixas e em outra área de Caatinga não manipulada no período chuvoso e transição águas-seca no ano de 2016. Avaliou-se a produção de biomassa herbácea e, a diversidade e equabilidade pelos índices de Shannon-Weaver (H') e Pielou (J') das áreas raleada em faixas e não manipulada. Foi ainda avaliado o estabelecimento dos capins massai e búffel ao centro e na lateral da área raleada em faixa. $\mathrm{Na}$ época das águas a produção de biomassa herbácea na área raleada em faixas e não manipulada foi de 1.228 $\mathrm{kg} \mathrm{ha}^{-1}$ e $833,33 \mathrm{~kg} \mathrm{ha}^{-1}$, enquanto o período de transição águas-seca $1.973 \mathrm{~kg} \mathrm{ha}^{-1}$ contra $836,00 \mathrm{~kg} \mathrm{ha}^{-1}$, respectivamente. Os índices permaneceram próximos H' $(1,86)$ e J' $(0,74)$, para a área raleada e H' $(1,77)$ e J' $(0,85)$ para a não manipulada. O capim-massai apresentou melhor estabelecimento e desenvolvimento que o capim-búffel no centro e na lateral da área raleada em faixas. O raleamento em faixas aumenta a biodiversidade da área contribuindo juntamente com o enriquecimento no incremento de biomassa de forragem herbácea.
\end{abstract}

Palavras-chave: Composição botânica. Capim-massai. Capim-búffel. Sombreamento. Pleno sol.

\footnotetext{
${ }^{*}$ Corresponding author

${ }^{1}$ Received for publication in 08/10/2018; accepted in 07/10/2019.

Paper extracted from the master dissertation of the first author.

${ }^{2}$ Departmente of Animal Science, Universidade Federal do Ceará, Fortaleza, CE, Brazil; jefte_arnon@hotmail.com - ORCID: 0000-00029470-0416,msocorro@ufc.br-ORCID: 0000-0002-6887-7111,magno@ufc.br - ORCID: 0000-0003-3573-6053.

${ }^{3}$ Center of Forage and Grassland, Empresa Brasileira de Pesquisa Agropecuária Caprinos e Ovinos, Sobral, CE, Brazil; ana.clara@embrapa.br - ORCID: 0000-0002-9685-569X, rafael.tonucci@embrapa.br - ORCID: 0000-0002-7511-4956.
} 


\section{INTRODUCTION}

The Caatinga biome is the main dry forest in Brazil, covering approximately $844,453 \mathrm{~km}^{2}$ and representing $11 \%$ of the entire Brazilian national territory; it is also one of the most inhabited semiarid regions in the world (ALVES; ARAÚJO; NASCIMENTO, 2009). Agriculture is among the most exploited activities the region. However, due to its short rainy season (3 to 4 months) (GUERREIRO et al., 2013), shallow soils, and different levels of fertility, this biome is very prone to desertification (AQUINO et al. 2017).

Because it is more resilient than agriculture, livestock production is the main activity in this region; it also has high social and economic impact because it offers animal protein and leather as source of subsistence and income (CORREIA et al., 2013). However, wood extraction driven by itinerant agriculture has led to an increase in degradation indexes and the disappearance of native Caatinga species (SANTOS et al., 2010).

Thinning, developed in the 1980s by Embrapa, is a technique that aims to manipulate in a targeted way the woody stratum, maintaining a soil cover of $20 \%$ for areas used for agriculture and $40 \%$ for the those used for livestock (SCHACHT; MALECHEK, 1989). Araújo Filho et al. (2002) evaluated a thinned Caatinga area and observed that forage production increased by $76 \%$ and the area maintained its botanical composition. Among the biomes where thinning has been initiated (savanna, forest and strips), the savanna model has been the most exploited; but limitations have been observed, such as a high dependence on labor, low establishment of grasses in consortium with the woody stratum, and significant loss of vigor of the native species (CAMPANHA et al., 2011).

Thinning the area into strips appears to solve the problems above, considering that forest strips intersect with deforested areas, guaranteeing a vegetation cover of around 40\% (ARAÚJO FILHO et al., 2002), and that it is possible to increase the herbaceous biomass production between the strips. Although this theoretical model exists, there are no studies that attest to the efficiency or benefits of this manipulation model, since part of the area must be deforested (FILHO; SILVA; CÉZAR, 2013). According to Seddaiu et al. (2013), the few studies aiming to evaluate interactions between woody and herbaceous strata have been limited to subtropical environments, and almost none have investigated semiarid regions.

Besides maintaining vegetation biodiversity, thinning into strips allows for the intensification of biomass production in the space between the strips, and for the annual herbaceous native pasture to become enriched with perennial grasses. The buffel grass is the most widely used forage species in these regions because it presents adaptive characteristics for dry lands. However, limitations have been reported, such as low seed quality and germination rate and the capacity of the native area for sustaining invasive species (MARSHALL; LEWIS; OSTENDORF., 2012). Recently another grass, the massai grass (Megathyrsus maximus 'Massai' syn. Panicum maximum 'Massai'), originally released for wetlands, has shown to be very promising and efficient for use in semiarid environments (CAVALCANTE et al. 2014).

Thus, the objective of this study was to quantify the impact of the thinning into strips method on the botanical composition of a Caatinga and to estimate the method's forage production potential when enriched with tropical forage grasses.

\section{MATERIAL AND METHODS}

Two trials were carried out at Embrapa (Goats and Sheep unit) in Sobral-CE, Brazil, from January to June of 2016, the first one in a Caatinga area thinned into strips $\left(03^{\circ} 44^{\prime} 35.71^{\prime \prime} \mathrm{S}\right.$ and $040^{\circ}$ $\left.21^{\prime} 56.09^{\prime \prime} \mathrm{W}\right)$ and an unmanipulated Caatinga area (Control) $\left(03^{\circ} 44^{\prime} 35.73^{\prime \prime} \mathrm{S}\right.$ and $040^{\circ} 21^{\prime}$ 56.06" W) and the second trial only in the area thinned into strips. Both areas were at an altitude of $83 \mathrm{~m}$. The area was thinned into strips (East/West) in 2015, perpendicular to the slope (North/South) of the area. Each area was approximately 3 ha.

The climate of the experimental area is semiarid of BShw' type, according to the Köppen classification (CARVALHO et al., 2004), with a rainy season from January to June. The average annual temperature is $28{ }^{\circ} \mathrm{C}$ and the average precipitation is $759 \mathrm{~mm}$ per year. There were patches of Typical Luvisol Chromic Ortic (more prevalent) and Typical Luvisol Hypochromic Ortic (less predominant), with a clay texture in the areas (AGUIAR et al., 2006).

In the Caatinga area thinned into strips, intact native vegetation $(15 \times 250 \mathrm{~m})$ and deforested area $(20 \times 250 \mathrm{~m})$ intersected, maintaining $35-40 \%$ woody cover in the whole area (deforested and intact), as recommendation for savanna thinning (ARAÚJO FILHO et al., 2002).

A soil sampling was performed $(0-10 \mathrm{~cm}$ deep) for the chemical composition analysis, with the following results: $\mathrm{pH}$ (5.4); O.M. (20.3 $\left.\mathrm{g} \mathrm{kg}^{-1}\right)$; P $\left(9.0 \mathrm{mg} \mathrm{dm}{ }^{-3}\right) ; \mathrm{K}\left(162.0 \mathrm{mg} \mathrm{dm}\right.$ ); $\mathrm{Ca}\left(36.0 \mathrm{mmol}_{\mathrm{c}}\right.$ $\left.\mathrm{dm}^{-3}\right) ; \mathrm{Mg}\left(43.0 \mathrm{mmol}_{\mathrm{c}} \mathrm{dm}^{-3}\right) ; \mathrm{H}+\mathrm{Al}\left(23.1 \mathrm{mmol}_{\mathrm{c}} \mathrm{dm}^{-}\right.$ $\left.{ }^{3}\right)$; SB $\left(85.0 \mathrm{mmol}_{\mathrm{c}} \mathrm{dm}^{-3}\right)$; CEC $\left(108.0 \mathrm{mmol}_{\mathrm{c}} \mathrm{dm}^{-3}\right)$; V $(78.0 \%)$. Due to the fertility of the soil, the foundation fertilization practice for the implantation of the second trial was not necessary.

The climatic data of temperature (maximum, average and minimum), average dew point, and precipitation (accumulated weekly) of the experimental site are presented in Figure 1. Precipitation data were collected from a pluviometer 
installed in the area, while the others were collected from a site in the INMET station in Sobral.

\section{TRIAL 01:}

The phytosociological survey, botanical composition and structural variables evaluation of the herbaceous and woody strata in the entire thinned -into-strips and control areas were all performed in two distinct periods: rainy season (Jan 07, 2016 to Mar 31, 2016) and rainy-dry transition (Apr. 01, 2016 to Jun. 30, 2016).

The herbaceous stratum considered all the species in a $0.250 \mathrm{~m}^{2}$ frame up to $1 \mathrm{~m}$ high and the woody stratum, shrubs and trees whose height was greater than $1.0 \mathrm{~m}$ and had a diameter at the ground level (DGL) above $3 \mathrm{~cm}$ (RODAL; SAMPAIO; FIGUEIREDO, 2013).

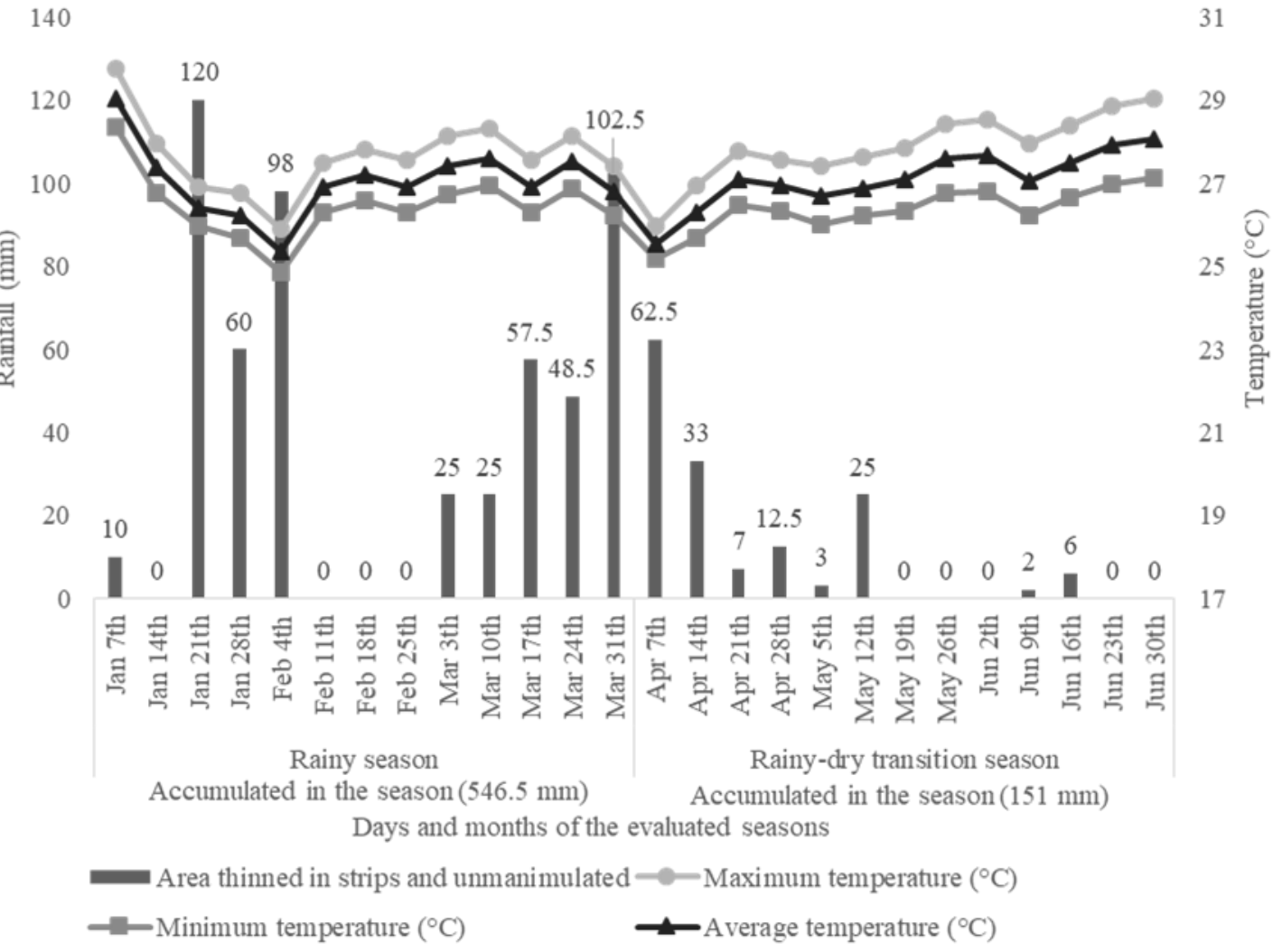

Figure 1. Maximum, average, and minimum temperature $\left({ }^{\circ} \mathrm{C}\right)$; average dew point $\left({ }^{\circ} \mathrm{C}\right)$; and precipitation $(\mathrm{mm})$ accumulated during the week in the evaluated seasons.

The design adopted included completely randomized blocks in a split-plots arrangement, with repeated measures in time (where the plots were the thinned-into-strips or control areas and the subplots were in the rainy and rainy-dry transition seasons), with four replications, with each trip being considered a replication.

The evaluated phytosociological variables were density, cover, and frequency of herbaceous and woody species. Diversity indexes such as the Shannon-Weaver (H') and Pielou (J') were calculated using the equations described below. The herbaceous stratum was evaluated by the visual method (applying a percentage value), the total soil coverage (\%), coverage by monocotyledons (\%), herbaceous dicotyledons (\%) and litter (\%), and the absolute frequency (\%).

$$
\text { A. F. }(\%)=\frac{N . \text { S.S. }}{\text { T. N.S. }} \times 100
$$

, where A.F. is the absolute frequency, N.S.S. is the number of sample units in which the species occurred, and T.N.S is the total number of sample units.

$$
\text { S. D. }\left(\frac{\text { indivídual }}{\text { ha }}\right)=\frac{10.000}{\mathrm{~A} \times \mathrm{N}} \text {, }
$$

where S.D corresponds to the specific density, $\mathrm{A}$ is the sampled area, and $\mathrm{N}$ is the total number of individuals sampled.

$$
\text { R.D. }(\%)=\frac{\text { S.D. }}{\text { T.D. }} \text {, where R.D. is the relative }
$$

density, S.D. is the specific density, and T.D. is the total density.

$$
\text { T. D. }\left(\frac{\text { plants }}{\text { ha }}\right)=\sum S . \text { D. where T.D is the total }
$$
density and S.D the specific density.

$$
\mathrm{H}^{\prime}=-\sum_{\mathrm{i}=1}^{\mathrm{s}} \frac{\mathrm{ni}}{\mathrm{N}} \mathrm{x} \ln \frac{\mathrm{ni}}{\mathrm{N}}
$$
diversity index of Shannon-Weaver (H'), ni is the number of individuals sampled for the $\mathrm{i}_{\text {th }}$ species, $\mathrm{N}$ is the total number of individuals sampled, and $\ln$ is the Napierian logarithm. 


$$
\mathrm{J}^{\prime}=\frac{\mathrm{H}^{\prime}}{\ln (\mathrm{S})} \text {, where } \mathrm{J}^{\prime} \text { corresponds to the }
$$
equability index of Pielou, $\mathrm{H}^{\prime}$ is the diversity index of Shannon-Weaver, $\ln$ is the Napierian logarithm, and $\mathrm{S}$ is the total number of species sampled.

For the quantification of the botanical composition of the native vegetation, vegetal species present in the experimental area were collected, herbalized, and identified according to the system protocol of APG III (APG, 2009). The species were grouped in forages (those recognized by animals) and non-forages (invasive, toxic, and low nutritive plants). The plants identified in this study received a number according to the work collection of the research project and were registered in the herbarium of Embrapa Goats and Sheep.

Structural variables of native pastures, especially the herbaceous stratum, were quantified. The total forage biomass $\left(\mathrm{kg} \mathrm{ha}^{-1}\right)$ and litter biomass $\left(\mathrm{kg} \mathrm{ha}^{-1}\right)$ in a frame of $0.25 \times 1.0 \mathrm{~m}$ were collected using the following variables: height $(\mathrm{cm})$, using a retractable graduated rod adapted from the type sward stick (Barthram, 1984) along the pasture; leaf area index (LAI) and interception of photosynthetically active radiation (IPAR, \%), using in agriculture analyzer PAR-LAI model Accupar LP -80 , with the readings taken below and above the herbaceous canopy. All variables were measured in a minimum number of 24 points in the Caatinga area thinned into strips and in the control.

The variables for the woody stratum are as follows: diameter at the base (DB) at $0.30 \mathrm{~m}$ from the ground; diameter at breast height $(\mathrm{DBH})$ at $1.3 \mathrm{~m}$ from ground; and height $(\mathrm{m})$ of the trees present in the plots of $15 \times 30 \mathrm{~m}\left(450 \mathrm{~m}^{2}\right)$, collected using a Finn caliper.

\section{TRIAL 2:}

The establishment criteria for perennial forage plants in area thinned into strips was evaluated. Two grasses were planted: massai grass (Megathyrsus maximus 'Massai' syn. Panicum maximum 'Massai') and buffel grass (Pennisetum ciliare 'Áridus' syn. Cenchrus ciliaris 'Áridus'), in shaded conditions and in full sun.

The shaded plots of buffel and massai grasses were on the right and left sides of the area thinned into strips, while the full sun treatment plots were in the center of the area thinned into strips; the latter was considered parallel to the range of the shaded condition.

The minimum sowing rate $\left(\mathrm{kg}\right.$ seeds ha $\left.{ }^{-1}\right)$ was calculated based on the cultural value, which for massai and buffel grasses were 21 and 1.2, respectively.

The two grasses were cultivated in $35-\mathrm{cm}-$ spaced rows in plots of $3 \times 3 \mathrm{~m}\left(9 \mathrm{~m}^{2}\right)$, at a depth of $2 \mathrm{~cm}$ for massai and $3 \mathrm{~cm}$ for buffel grass, when the soil was wet-indicating the beginning of the rainy season. The seedlings were fertilized with $67 \mathrm{~g}$ of nitrogen, equivalent to $300 \mathrm{~kg} \mathrm{ha}^{-1}$, with urea as the nitrogen source, at 16 days post germination in the low technological level condition (SFCST, 1999). To evaluate the establishment criteria, physiological and structural variables of massai grass and buffel grass were quantified.

The design was completely randomized, with four replications, where the experimental units were the plots in full sun or shaded.

Physiological variables were collected 60 days after germination (LOPES et al., 2013). Two devices were used: infrared gas exchange analyzer (IRGA) model LC-Pro-SD and chlorophyllometer model SPAD-502. Measurements were taken on the last newly expanded leaf of the plants in the intermediate growing position within the plot. The day before the measurements, a daily round was done every $2 \mathrm{~h}(06: 00,08: 00,10: 00,12: 00,14: 00$, and 16:00) to determine the maximum photosynthetic rate; 10:00 was used for the shading treatment and 08:00 for the full sun exposure treatment. The variables collected were leaf

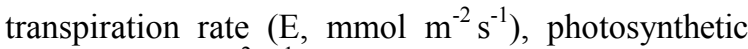
rate $\left(\mathrm{A}, \mu \mathrm{mol} \mathrm{m} \mathrm{m}^{-2} \mathrm{~s}^{-1}\right)$, stomatal conductance rate (gs, mol m $\left.\mathrm{s}^{-1}\right)$, internal concentration of carbon dioxide $(\mathrm{Ci}, \mathrm{ppm})$, internal leaf temperature $\left(\mathrm{T}_{\text {Leaf }},{ }^{\circ} \mathrm{C}\right)$, carboxylation rate $(\mathrm{A} / \mathrm{Ci})$, intrinsic water use efficiency $(\mathrm{A} / \mathrm{E})$, and chlorophyll relative index (SPAD units).

The structural parameters were evaluated at 80 days post germination, at which point the establishment cut was made and the following variables were quantified: total biomass $(\mathrm{kg}$ of dry matter per hectare) and its fractions (leaf blade, stem and dead material $\mathrm{kg} \mathrm{ha}^{-1}$ ) cut at ground level, and population density of tillers (PDT, plants $\mathrm{m}^{-2}$ ) by using a frame of $0.5 \times 0.5 \mathrm{~m}\left(0.25 \mathrm{~m}^{2}\right)$; height $(\mathrm{cm})$; LAI and IPAR (\%) by using the analyzer equipment PAR-LAI in the agriculture model Accupar LP-80, with the readings taken below and above the canopy of the massai and buffel grasses; and number of live leaves per tiller (NLL). Rainfall use efficiency (RUE) was also quantified and expressed in $\mathrm{kg} \mathrm{ha}^{-1}$ $\mathrm{mm}^{-1}$, according to the equation of Turner (2004):

$$
\mathrm{RUE}=\frac{\mathrm{TFB}}{\mathrm{AR}} \text {, where TFB is the total forage }
$$

biomass and AR the accumulated rainfall.

A descriptive statistic was used for the phytosociological and botanical composition parameters. The other variables were submitted to a normality test by Shapiro-Wilk's test $(\mathrm{P}<0.05)$ and homoscedasticity by Bartlett's test $(\mathrm{P}<0.05)$. The structural and physiological characteristics data were submitted for analysis of variance (ANOVA). Interactions were designated as significant by the $\mathrm{F}$ test $(\mathrm{P}<0.05)$ and the means were compared by Tukey's test $(\mathrm{P}<0.05)$.

As a tool for statistical analysis, the MIXED procedure of the software SAS (SAS Institute, 
version 9.3) was adopted, treating the area manipulated in strips with the grass species as fixed effects.

\section{RESULTS AND DISCUSSION}

\section{TRIAL 01:}

The thinning of the Caatinga into strips promoted the emergence of herbaceous species during both seasons evaluated compared more than the control area did (Table 1). The thinning of the area into strips may contribute to increasing the carrying capacity of that area. According to Aguiar et al. (2013), an increase in plant biodiversity may contribute to the production of herbaceous biomass, favoring animal production. Smith, Gros and Robertson (2008) observed that heterogeneous environments are more resilient than homogeneous environments due to the fact that the species that grow there become more efficient at using natural resources, mainly nutrients and groundwater.

In the woody stratum, the area thinned into strips presented more botanical families (7) than that in the control area (5) (Table 1). Of these families, only Malvaceae (with the species Pseudobombax marginatum Hill.Juss. \& Cambess.Robyns) and Rhamnaceae (with the species Ziziphus joazeiro Mart.) appeared exclusively in the area thinned into strips. These species are protected by law (ALBUQUERQUE et al., 2007) because they disappear with the succession process. One of the principles of thinning is to preserve the native species of the region protected by law, and our results suggest that this technique, besides boosting the production of biomass, also succeeds in protecting such native species.

The woody stratum species in the area thinned into strips that presented the highest A.F. $(100 \%)$ and density (121 individuals $\mathrm{ha}^{-1}$ ) was Cordia oncocalyx Allemão (Boraginaceae). Mendes et al. (2013a), evaluating C. oncocalyx, observed that the species was more resistant to drought in the thinned area than the unmanipulated one. This may be associated with the fact that trees in agroforestry systems keep their leaves for a longer period than that by plants in unmanipulated systems. According to Mendes et al. (2013b), this species has a root system that favors the supply of water to native and/ or cultivated herbaceous species, mainly by flowing through the trunk. This is associated with the increase in the photosynthetic rate of this species, which in thinned areas is superior to that in unmanipulated areas.
The thinning of the Caatinga into strips favored the appearance of functional species of forages during the two evaluated seasons (Table 1), with an increase of $21.2 \%$ during the rainy season and $73.2 \%$ during the rainy-dry transition season. This increase is mainly due to the emergence of species such as Jacquemontia gracillima Choisy. Hallierf, Centrosema pubescens Benth, Mimosa caesalpiniaefolia Benth, and Phaseolus patyroides Linnaeus, all of which appeared in the area thinned into strips. This response is an effect of the reduced competition for light and nutrients, which in turn is a result of the reduced tree density. According to Silva et al. (2017), an ideal woody cover in semiarid regions generates several benefits for the production system, such as reduced evapotranspiration of the species and increased energy flow of the system; both of these also increase the number of forage species and consequently biomass production. Aguiar et al. (2013) studied a thinned Caatinga area and observed an increment in herbaceous forage biomass production compared to the unmanipulated Caatinga area, and a production similar to that of a fully deforested area.

Some herbaceous species have appeared exclusively in the area thinned into strips. Among them, Jacquemontia gracillima Choisy. Hallierf stood out, with $12.5 \%$ A.F. during the rainy season and $25 \%$ during the rainy-dry transition season. According to Linhares et al. (2010), this species can produce 32 tons of green biomass ha $^{-1}$ year $^{-1}$ and presents satisfactory nutritional levels in its protein, calcium and phosphorus compositions; this is reasonable considering that it adapted to the semiarid conditions. Another species that deserves to be highlighted is Arachis dardani Krapov. \& Wing. Coutu. Gregory, which presented higher A.F. values in the Caatinga area thinned into strips during both rainy $(51.40 \%)$ and rainy-dry transition $(5.60 \%)$ seasons compared to those of the control area, which had values of 40.10 and $4.20 \%$, respectively (Table 1). The appearance of the spontaneous form of that species in the area thinned into strips is important, since in Brazil it is used as a way to improve the nutritive quality of pastures (LUDWING et al., 2010).

Stylosanthes spp. in the legume family were observed in the area thinned into strips during the two evaluated seasons, but they were only observed in the control area during the rainy season. Forage legumes contribute to the recovery of the area since they have the capacity to fix nitrogen in the soil, favoring the sustainability of the production system (BARCELOS et al., 2008). 
Table 1. Botanical identification (family and scientific name), absolute frequency (A.F.\%) of species of the herbaceous stratum during two seasons (rainy and rainy-dry transition) and absolute frequency (A.F.\%), specific density (S.D., individuals $\mathrm{ha}^{-1}$ ) and total density (Total Dens. individuals $\mathrm{ha}^{-1}$ ) of woody stratum species during the rainy season in the Caatinga area thinned into strips (Thinn.) and control area (Contr.) in Sobral/CE in 2016.

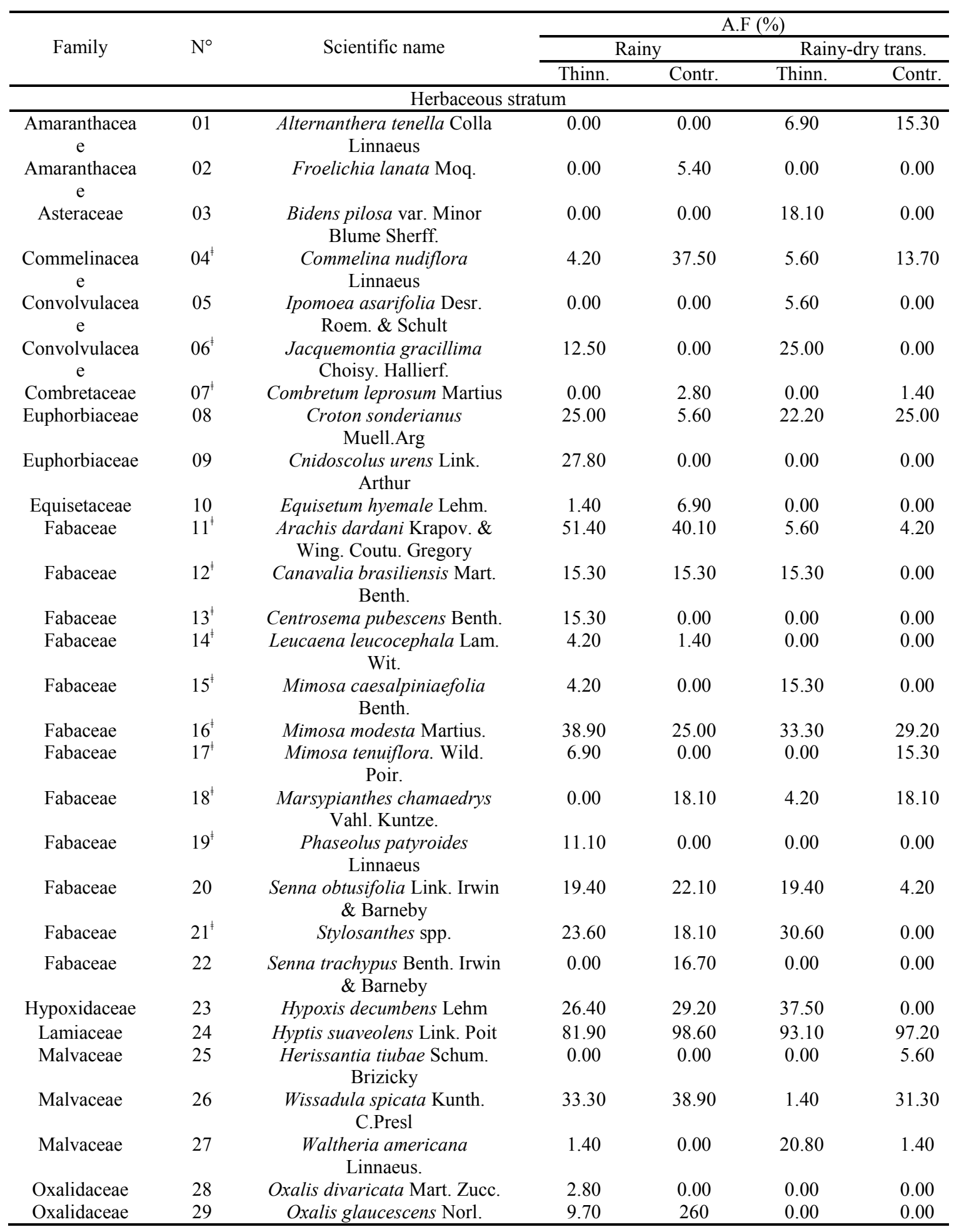

Identification number given to the species according to the alphabetical order of the family $\left(\mathrm{N}^{\circ}\right)$

${ }^{\ddagger}$ Forage species. 
Table 1 continued.

\begin{tabular}{|c|c|c|c|c|c|c|}
\hline \multirow{3}{*}{ Family } & \multirow{3}{*}{$\mathrm{N}^{\circ}$} & \multirow{3}{*}{ Scientific name } & \multicolumn{4}{|c|}{ A.F (\%) } \\
\hline & & & \multicolumn{2}{|c|}{ Rainy } & \multicolumn{2}{|c|}{ Rainy-dry trans. } \\
\hline & & & Thinn. & Contr. & Thinn. & Contr. \\
\hline \multicolumn{7}{|c|}{ Herbaceous stratum } \\
\hline Poaceae & $30^{\ddagger}$ & $\begin{array}{c}\text { Anthephora hermaphrodita } \\
\text { Link. Kuntze. }\end{array}$ & 26.40 & 5.60 & 0.00 & 0.00 \\
\hline Poaceae & $31^{\ddagger}$ & $\begin{array}{c}\text { Aristida adscencionis } \\
\text { Linnaeus. }\end{array}$ & 0.00 & 0.00 & 9.70 & 0.00 \\
\hline Poaceae & $32^{\ddagger}$ & $\begin{array}{c}\text { Brachiaria plantaginea Link. } \\
\text { Hitchc }\end{array}$ & 41.70 & 45.80 & 10.90 & 2.80 \\
\hline Portulacaceae & 33 & Portulaca oleracea Linnaeus & 0.00 & 1.40 & 1.40 & 0.00 \\
\hline Plantaginaceae & 34 & Scoparia dulcis Kuntze & 4.20 & 0.00 & 0.00 & 0.00 \\
\hline Rubiaceae. & 35 & $\begin{array}{c}\text { Borreria verticillata } \mathrm{L} . \mathrm{G} . \\
\text { Mey }\end{array}$ & 0.00 & 0.00 & 55.60 & 37.50 \\
\hline Verbenaceae & 36 & Lippia sidoides Cham. & 00 & 0.00 & 11.10 & 0.00 \\
\hline Verbenaceae & 37 & Lantana camara Linnaeus. & 45.80 & 91.70 & 8.30 & 1.40 \\
\hline Verbenaceae & 38 & Lippia alba Mill. Brown & 0.00 & 9.70 & 0.00 & 0.00 \\
\hline Vitaceae & 39 & $\begin{array}{c}\text { Parthenocissus tricuspidata } \\
\text { Planch. }\end{array}$ & 1.40 & 0.00 & 0.00 & 0.00 \\
\hline Turneraceae & 40 & Turnera subulata Smith. & 0.00 & 0.00 & 8.30 & 0.00 \\
\hline \multirow{2}{*}{\multicolumn{3}{|c|}{ Woody stratum }} & \multicolumn{2}{|c|}{ A.F. $(\%)$} & \multicolumn{2}{|c|}{ S.D. (individuals $\mathrm{ha}^{-1}$ ) } \\
\hline & & & Thinn. & Contr. & Thinn. & Contr. \\
\hline Apocynaceae & 41 & Aspidosperma pyrifolium Mart & 41.70 & 75.00 & 8.00 & 22.00 \\
\hline Boraginaceae & $42^{\ddagger}$ & Cordia oncocalyx Allemão & 100.00 & 100.00 & 121.00 & 194.00 \\
\hline Combretaceae & $43^{\ddagger}$ & Combretum leprosum Martius & 75.00 & 50.00 & 14.00 & 17.00 \\
\hline Euphorbiaceae & 44 & Croton sonderianus Müll. Arg & 75.00 & 100.00 & 37.00 & 217.00 \\
\hline Fabaceae & 45 & $\begin{array}{c}\text { Amburana cearensis Allemão. } \\
\text { Smith }\end{array}$ & 41.70 & 0.00 & 6.00 & 0.00 \\
\hline Fabaceae & 46 & $\begin{array}{c}\text { Libidibia ferrea Mart. Tui. } \\
\text { Queiroz }\end{array}$ & 91.70 & 75.00 & 19.00 & 28.00 \\
\hline Fabaceae & $47^{\ddagger}$ & Mimosa tenuiflora Willd. Poir & 66.70 & 100.00 & 25.00 & 94.00 \\
\hline Fabaceae & $48^{\ddagger}$ & Mimosa arenosa Willd. Poir & 91.70 & 100.00 & 49.00 & 72.00 \\
\hline Fabaceae & $49^{\ddagger}$ & $\begin{array}{c}\text { Mimosa caesalpiniaefolia } \\
\text { Benth }\end{array}$ & 100.00 & 100.00 & 96.00 & 83.00 \\
\hline Fabaceae & $50^{\ddagger}$ & Poincianella pyramidalis Tui. & 8.30 & 0.00 & 1.00 & 0.00 \\
\hline Malvaceae & 51 & $\begin{array}{c}\text { Pseudobombax marginatum } \\
\text { Hill. Robyns }\end{array}$ & 8.30 & 0.00 & 1.00 & 0.00 \\
\hline Rhamnaceae & $52^{\ddagger}$ & Ziziphus joazeiro Martius & 25.00 & 0.00 & 2.00 & 0.00 \\
\hline Total Dens. (ind & Ials & & & & 379.00 & 728.00 \\
\hline
\end{tabular}

Identification number given to the species according to the alphabetical order of the family $\left(\mathrm{N}^{\circ}\right)$

${ }^{\ddagger}$ Forage species.

The Caatinga area thinned into strips presented Shannon-Weaver (H') and Pielou (J') diversity indexes than the control (Figure 2A). According to Drobnik et al. (2011), improved management strategies may favor the emergence of new species and promote the sustainability of the system.

A great advantage thinning an area into strips is that it maintains local biodiversity in addition to promoting a greater production of forage biomass. According to Versieux et al. (2011), when the Caatinga is manipulated in a disorderly way, it causes a reduction in floral biodiversity, which is illustrated in these indexes. The $\mathrm{DBH}$ and height variables were not different $(\mathrm{P}>0.05)$ between the thinned into strips and control areas (Figure 2B), demonstrating that thinning into strips maintained the structure of the trees.

Two species in the woody stratum with deciduous characteristics-Croton sonderianus Muell.Arg (217 individuals $\left.\mathrm{ha}^{-1}\right)$ and Cordia oncocalyx Allemão (194 individuals ha ${ }^{-1}$ ) (Table 1) in the control area-contributed to the variable litter coverage (Table 2). As there was a higher density of these species, they deposited a greater amount of this material in the area. 


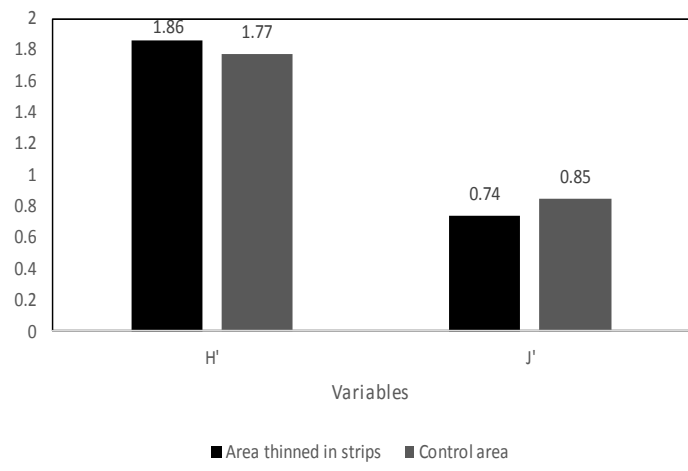

(A)

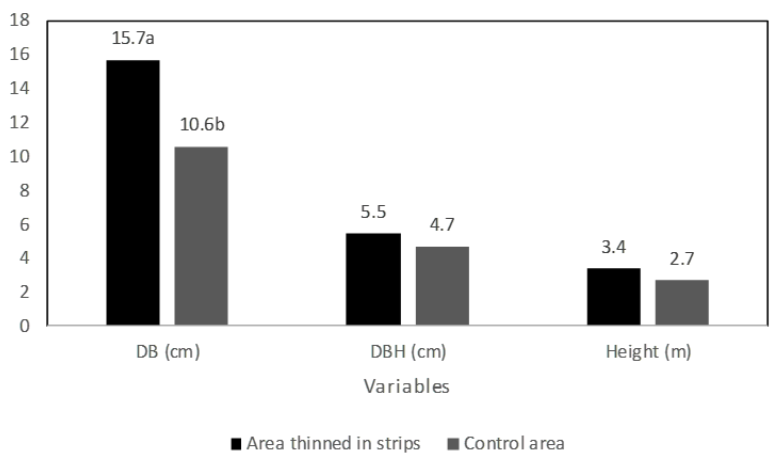

(B)

Figure 2. Shannon-Weaver (H') and Pielou (J') Indexes (A) and structural variables (DB, DBH and height) (B) of the woody stratum in the Caatinga area thinned into strips and control area in Sobral/CE in 2016.

Means followed by different letters, inside each structural variable, differ by the Tukey's test $(\mathrm{P}<0.05)$.

Diameter at base height $(\mathrm{DB}, \mathrm{cm})$ and diameter at breast height $(\mathrm{DBH}, \mathrm{cm})$.

When the effect was not identified as significant, its corresponding letters were not included in the figure.

There was no interaction for manipulation $\times$ period among these variables: total soil coverage, mono and dicotyledons herbaceous $(\%)$ for both thinned into strips and control areas. However, there was a significant difference between the treatments $(\mathrm{P}<0.0001)$ in total soil coverage of the soil and monocotyledons according to the evaluated season; the rainy season presented the highest mean and the rainy-dry transition season the lowest (Table 2), which was due to the ephemeral character of monocotyledons (Table 1). According to Silva et al. (2017), the high evapotranspiration and temperatures, which are associated with low precipitation, promote a rapid disappearance of native herbaceous species, which contributes to them completing their growth cycle faster (ephemeral).

The monocotyledon species showed a lower absolute frequency (\%) and contributed little to the production of total biomass $\left(\mathrm{kg} \mathrm{ha}^{-1}\right)$. Highlighted in this fraction was the presence of Brachiaria plantaginea Link Hitchc in $10.9 \%$ of the frames thrown in the area thinned into strips and $2.3 \%$ in the control area (Table 1). These values add a new perspective to the increase in the number of those species over the time in the area thinned into strips, since this environment provides ideal conditions, such as the incidence of light and the rapid dispersion of seeds.

Total forage biomass (TFB) was superior in the area thinned into strips, with the highest production during the two seasons evaluated (rainy and rainy-dry transition) being $35 \%$ in the rain and $135 \%$ rainy-dry. This increase can be explained by the herbaceous plants using radiation more efficiently, which promoted an acceleration in the growth and biomass production rates (SILVA et al., 2009). Another factor that influenced TFB was the presence of herbaceous dicotyledons in the area thinned into strips, with an emphasis on the species Hyptis suaveolens Link. Poit. Pereira Filho et al. (2007) demonstrated that, besides increasing local biodiversity, the Caatinga thinning in their study lead to an $80 \%$ increase in the availability of herbaceous forage biomass harvested. That species was also mainly responsible for the significant difference $(\mathrm{P}<0.0001)$ in height of the herbaceous stratum - the lowest value was observed during the rainy season $(25.33 \mathrm{~cm})$ and the highest during the rainy-dry transition season $(53.52 \mathrm{~cm})$. This response was due to the increase in A.F. (\%) in the area thinned into strips. According to Rodrigues et al. (2012), $H$. suaveolens grows and establishes itself rapidly in the area and can reach up to $2 \mathrm{~m}$ high.

Interaction (manipulation $\times$ period) occurred for the variables LAI and IPAR, both of which were significantly different $(\mathrm{P}<0.0011$ for $\mathrm{LAI}$ and $\mathrm{P}<0.0053$ for IPAR) between rainy and rainy-dry transition seasons. The thinning of the Caatinga into strips decreases the density of trees, and this is reflected in the lower LAI in our results. Shaded herbaceous plants tend to elongate their stems and alter their leaf angles, making them flatter to improve light uptake (LARCHER, 2006). For IPAR, the rainy-dry transition season presented the lowest mean for the area thinned into strips.

The high coefficients of variation $(\mathrm{CV})$ observed in the research is due to the fact that this study was carried out in a rangeland located in a biome with rich biodiversity and variable climatic parameters. 
Table 2. Coverage components, biomass, height, leaf area index and interception of photosynthetically active radiation of the herbaceous stratum in Caatinga area thinned into strips and control area in Sobral/CE in 2016.

\begin{tabular}{|c|c|c|c|}
\hline Manipulation & Rainy season & Rainy-dry transition season & Mean \\
\hline \multicolumn{4}{|c|}{ Total soil coverage $(\%)(\mathrm{CV}=30.24 \%)$} \\
\hline Thinned into strips & 50.76 & 48.40 & 49.58 \\
\hline Control & 66.87 & 43.82 & 55.35 \\
\hline Average & $58.82^{\mathrm{a}}$ & $46.11^{\mathrm{b}}$ & \\
\hline \multicolumn{4}{|c|}{ Herbaceous monocotyledons coverage $(\%)(\mathrm{CV}=109.42 \%)$} \\
\hline Thinned into strips & 6.74 & 1.53 & 4.13 \\
\hline Control & 5.85 & 0.03 & 2.94 \\
\hline Average & $6.29^{\mathrm{a}}$ & $0.78^{\mathrm{b}}$ & \\
\hline \multicolumn{4}{|c|}{ Herbaceous dicotyledons coverage $(\%)(\mathrm{CV}=38.29 \%)$} \\
\hline Thinned into strips & 30.80 & 46.25 & 38.53 \\
\hline Control & 33.04 & 29.10 & 31.10 \\
\hline Average & 31.92 & 37.66 & \\
\hline \multicolumn{4}{|c|}{ Litter coverage $(\%)(\mathrm{CV}=95.14 \%)$} \\
\hline Thinned into strips & $13.20^{\mathrm{Ba}}$ & $0.55^{\mathrm{Aa}}$ & 6.88 \\
\hline Control & $27.99^{\mathrm{Aa}}$ & $12.64^{\mathrm{Ab}}$ & 20.31 \\
\hline Average & 20.59 & 6.60 & \\
\hline \multicolumn{4}{|c|}{ Total forage biomass $\left(\mathrm{TFB}, \mathrm{kg} \mathrm{ha}^{-1}\right)(\mathrm{CV}=56.98 \%)$} \\
\hline Thinned into strips & $1,128.98^{\mathrm{Ab}}$ & $1,973.61^{\mathrm{Aa}}$ & $1,551.29$ \\
\hline Control & $833.40^{\mathrm{Aa}}$ & $836.32^{\mathrm{Ba}}$ & 834.86 \\
\hline Average & 981.19 & $1,404.96$ & \\
\hline \multicolumn{4}{|c|}{ Litter biomass $\left(\mathrm{LB}, \mathrm{kg} \mathrm{ha}^{-1}\right)(\mathrm{CV}=133.00 \%)$} \\
\hline Thinned into strips & $373.33^{\mathrm{Ba}}$ & $59.44^{\mathrm{Aa}}$ & 216.39 \\
\hline Control & $1,490.55^{\mathrm{Aa}}$ & $253.33^{\mathrm{Ab}}$ & 871.94 \\
\hline Average & 931.94 & 156.94 & \\
\hline \multicolumn{4}{|c|}{ Height of the herbaceous stratum $(\mathrm{cm})(\mathrm{CV}=44.64 \%)$} \\
\hline Thinned into strips & 21.16 & 51.71 & 36.44 \\
\hline Control & 29.89 & 55.33 & 42.61 \\
\hline Average & $25.53^{\mathrm{b}}$ & $53.52^{\mathrm{a}}$ & \\
\hline \multicolumn{4}{|c|}{ Leaf area index $(\mathrm{LAI})(\mathrm{CV}=69.59 \%)$} \\
\hline Thinned into strips & $3.67^{\mathrm{Ba}}$ & $0.74^{\mathrm{Ab}}$ & 2.21 \\
\hline Control & $5.12^{\mathrm{Aa}}$ & $1.39^{\mathrm{Ab}}$ & 3.26 \\
\hline Average & 4.40 & 1.10 & \\
\hline \multicolumn{4}{|c|}{ Interception of photosynthetically active radiation (IPAR, $\%)(\mathrm{CV}=34.79 \%)$} \\
\hline Thinned into strips & $83.10^{\mathrm{Aa}}$ & $37.91^{\mathrm{Bb}}$ & 60.50 \\
\hline Control & $89.81^{\text {Aa }}$ & $55.70^{\mathrm{Ab}}$ & 72.75 \\
\hline Average & 86.44 & 46.80 & \\
\hline
\end{tabular}

Means followed by distinct letters, uppercase in the column and lowercase in the row, within each variable differ by Tukey's test $(\mathrm{P}<0.05)$.

When significant interaction was detected, the letters were left at the center of each variable and not in the mean; when no significant interaction was observed, the letters were left only in the mean.

\section{TRIAL 02:}

Buffel and massai grasses were established, but since the buffel grass did not germinate, only the massai grass was analyzed and the conditions of full sun exposure and shade were considered as treatments, the former being located in the center and the latter on the left and right sides of the area thinned into strips. The buffel grass did not germination at first probably because it was dormant. According Santos et al. (2013), climatic factors such as low rainfall or high temperatures, reduce the germination of this species, reducing the break of physiological dormancy.

Structural and production variables of the massai grass were not significantly different $(\mathrm{P}>0.05)$ (Table 3); that is, the thinning of the Caatinga into strips did not decrease forage biomass production, since $40 \%$ of the coverage was manipulated by removing some trees, aiming to enable herbaceous growth and avoid erosion. This response was possibly due to the North/South direction of the strips in the thinned area, which allowed the seedlings to receive at least 6 hours of solar radiation per day; this temporary shading was not characterized as a limiting factor to seed growth. Silva et al. (2012), evaluating seven forage species in a consortium with pinhão-manso (Jatropha curcas L.), cultivated an area of Caatinga in rows and observed that the massai grass was the species that presented the highest constancy of growth and a greater accumulation of dry matter. They were not limited by the shade provided by the abovementioned arboreous species, since shading favors the mineralization of nitrogen by soil microorganisms. 
The variables internal concentration of carbon dioxide $(\mathrm{Ci})$, leaf transpiration rate $(\mathrm{E})$, stomatal conductance rate (gs), photosynthetic rate (A), relative index of chlorophyll $a$ and $b$ (SPAD), rate of carboxylation $(\mathrm{A} / \mathrm{Ci})$, and intrinsic water use efficiency (A/E) were not significantly different $(\mathrm{P}>0.05)$. However, internal leaf temperature $\left(\mathrm{T}_{\text {Leaf }}\right)$ did $(\mathrm{P}<0.05)$ - it had the lowest mean in the massai grass exposed to full sun and the highest in the shaded condition (Table 3 ). This response can be explained by the time at which these variables were measured before a daily round, as mentioned in the material and methods section. The readings were carried out on the plants in full sun exposure at 08:00 and shaded plants at 10:00, and this may have contributed to the rise in $\mathrm{T}_{\text {Leaf }}$ of shaded plants and improved their photosynthetic efficiency. According to Mendes et al. (2013b), the coverage of trees in semiarid environments can promote some physiological changes in the sub-forest, among them a decrease in leaf transpiration.

Because the grass was cultivated in a region characterized by high climatic variation (Figure 1) during the rainy season, this factor was attributed to the CV's variation in the analyzed variables.

Table 3. Structural and physiological variables of Massai grass grown under full sun exposure and shaded conditions in the area of Caatinga thinned into strips in Sobral/CE during the rainy season of 2016.

\begin{tabular}{|c|c|c|c|c|c|}
\hline \multicolumn{6}{|c|}{ Structural } \\
\hline Variables & Full sun & Shaded & Mean & CV (\%) & P-Value \\
\hline TFB $\left(\mathrm{kg} \mathrm{ha}^{-1}\right)$ & $1,445.00$ & 772.80 & $1,108.70$ & 73.20 & 0.2859 \\
\hline GLB $\left(\mathrm{kg} \mathrm{ha}^{-1}\right)$ & 821.00 & 377.20 & 599.10 & 79.70 & 0.2366 \\
\hline GSB $\left(\mathrm{kg} \mathrm{ha}^{-1}\right)$ & 341.70 & 149.60 & 245.70 & 101.50 & 0.3182 \\
\hline DFB $\left(\mathrm{kg} \mathrm{ha}^{-1}\right)$ & 281.80 & 247.30 & 264.50 & 54.50 & 0.7457 \\
\hline PDT (plants $\mathrm{m}^{-2}$ ) & 496.00 & 520.50 & 508.30 & 48.01 & 0.8917 \\
\hline NLL & 3.00 & 2.80 & 2.90 & 10.00 & 0.5158 \\
\hline IPAR (\%) & 0.50 & 0.58 & 0.51 & 29.30 & 0.4087 \\
\hline LAI & 1.30 & 1.32 & 1.30 & 64.90 & 0.9359 \\
\hline Height $(\mathrm{cm})$ & 33.30 & 22.10 & 27.70 & 29.30 & 0.0976 \\
\hline RUE & 3.80 & 2.00 & 2.90 & 73.20 & 0.2860 \\
\hline \multicolumn{6}{|c|}{ Physiological } \\
\hline Variables & Full sun & Shaded & Mean & CV (\%) & P-Value \\
\hline $\mathrm{T}_{\text {Leaf }}\left({ }^{\circ} \mathrm{C}\right)$ & $32.50^{b}$ & $40.60^{\mathrm{a}}$ & ----- & 4.36 & 0.0004 \\
\hline $\mathrm{Ci}(\mathrm{ppm})$ & 167.00 & 220.80 & 193.90 & 48.8 & 0.4524 \\
\hline $\mathrm{E}\left(\mathrm{mmol} \mathrm{m} \mathrm{m}^{-2} \mathrm{~s}^{-1}\right)$ & 0.40 & 0.60 & 0.50 & 70.15 & 0.3674 \\
\hline $\mathrm{gs}\left(\mathrm{mol} \mathrm{m} \mathrm{s}^{-2} \mathrm{~s}^{-1}\right)$ & 0.03 & 0.01 & 0.02 & 70.35 & 0.3308 \\
\hline $\mathrm{A}\left(\mu \mathrm{mol} \mathrm{m} \mathrm{m}^{-2} \mathrm{~s}^{-1}\right)$ & 5.10 & 3.40 & 4.30 & 47.59 & 0.2780 \\
\hline SPAD & 27.40 & 25.30 & 26.40 & 12.71 & 0.4037 \\
\hline $\mathrm{A} / \mathrm{Ci}$ & 0.04 & 0.02 & 0.03 & 70.39 & 0.1546 \\
\hline $\mathrm{A} / \mathrm{E}$ & 1.20 & 0.60 & 0.90 & 38.26 & 0.0582 \\
\hline
\end{tabular}

Means followed by the same lowercase letter in the row do not differ statistically by the Tukey's test (0.05). Number of live leaves per tiller (NLL); Total forage dry biomass (TFB); Green leaf dry biomass (GLB); Green stem dry biomass (GSB); Dead forage dry biomass (DFB); Population density of tillers (PDT); Leaf area index (LAI); Interception of photosynthetically active radiation (IPAR) and Rainfall use efficiency (RUE); Internal leaf temperature $\left(\mathrm{T}_{\text {leaf }}\right)$; Internal concentration of carbon dioxide $(\mathrm{Ci})$; Leaf transpiration rate $(\mathrm{E})$; Stomatal conductance rate (gs); Photosynthetic rate (A); Relative index of chlorophyll a and b; Rate of carboxylation (A/Ci) and Intrinsic water use efficiency $(\mathrm{A} / \mathrm{E})$.

When significant effect was detected, the letters were left in the table.

The coverage promoted by thinning into strips did not affect the production and physiology of the grasses, since it favored an increase of biomass. According to Pedreira, Pedreira and Lara (2015), integration systems that allow a transmittance of radiation to the herbaceous stratum $\leq 1,800 \mu \mathrm{mol}$ photon $\mathrm{m}^{-2} \mathrm{~s}^{-1}$ are ineffective for the stability of the production system.

\section{CONCLUSIONS}

Thinning into strips is a management option for the Caatinga that favors a quantitative increase 
the biomass pasture and the botanical composition of native species. This technique favors a large number of monocotyledon and dicotyledon forage species; it also allows the establishment of exotic species such as the massai grass, independent of its planting position in the area thinned into strips, which increases the forage biomass produced throughout the year and maintains the biodiversity in the area.

\section{REFERENCES}

AGUIAR, M. I. et al. Does biomass production depend on plant community diversity? Revista Agroforestry Systems, v. 87, n. 3, p. 699-711, 2013.

AGUIAR, M. I. et al. Perdas de solo, água e nutrientes em sistemas agroflorestais no município de Sobral, CE. Revista Ciência Agronômica, v. 37, n. 3, p. 270-278, 2006.

AQUINO, D.N. et al. Nutrient Cycling and CO2 Emissions in áreas of Preserved and Thinned Caatinga. Revista Árvore, v. 41, n. 3, p. e410308, 2017.

ANGIOSPERM PHYLOGENY GROUP - APG. An update of the Angiosperm Phylogeny Group classification for the orders and families of flowering plants: APG III. Botanical Journal of the Linnean Society, v. 161, n. 2, p. 105-121, 2009.

ALVES, J. J. A.; ARAÚJO, M. A.; NASCIMENTO, S. S. Degradação da Caatinga: Uma investigação Ecogeográfica. Revista Caatinga, v. 22, n. 3, p. 126 $-135,2009$

ARAÚJO FILHO, J. A. et al. Efeitos da manipulação da vegetação lenhosa sobre a produção e compartimentalização da fitomassa pastável de uma caatinga sucessional. Revista Brasileira de Zootecnia, v. 31, n. 1, p. 11-19, 2002.

ALBUQUERQUE, U. P. Medicinal and magic plants from a public Market in northeastern Brazil. Journal of Ethnopharmacoly, v. 110, n. 1, p. 7691, 2007.

BARCELOS, A. O. et al. Sustentabilidade da produção animal baseada em pastagens consorciadas e no emprego de leguminosas exclusivas, na forma de banco de proteína, nos trópicos brasileiros. Revista Brasileira de Zootecnia, v. 37, sup., p.5167, 2008.

BARTHRAM GT. Experimental tecniques: the HFRO sward stick. 1984. Penicuik: Hill Farming Research Organization, 1986, p.29-30 (Biennal Report 1984-1985).
CARVALHO, F. C. et al. Desempenho produtivo de ovelhas crioulas em um sistema de produção agrossilvipastoril, no semi-árido brasileiro. Agrossilvicultura, v. 1, n. 2, p. 81-90, 2004.

CAMPANHA, M. M. et al. Estrututura da comunidade vegetal arbóreo-arbustiva de um sistema agrossilvipastoril, em Sobral - Ce. Revista Caatinga, v. 24, n. 3, p. 94-101, 2011.

CAVAlCANTE, A. C. R. et al. Potential Use of Tropical Grass for Deferment in Semi-Arid Region. American Journal of Plant Sciences, v. 5, n. 7, p. 907-914, 2014

CORREIA, B. R. et al. Sistemas produtivos de caprinocultura leiteira no semiárido parabiano: caracterização, principais limitantes e avaliação de estratégias de intervenção. Pesquisa Veterinária Brasileira, v. 33, n. 3, p. 345-352, 2013.

DROBNIK, J. et al. Adaptation of plant functional group composition to management changes in calcareous grassland. Agricuture, Ecosystems \& Environment, v. 145, n. 1, p. 29-37, 2011.

GUERREIRO, M.J.S. et al. long-term variation of precipitation índices in Ceará State, Northeast Brazil. International Journal of Climatology, v. 33, n. 14, p. $2929-2939,2013$

LARCHER, W. Ecofisiologia vegetal. 2. ed. São Carlos-SP: Rima Editora, 2006. p.550.

LOPES, M. N. et al. Fluxo de biomassa em capimmassai durante o estabelecimento e rebrotação com e sem adubação nitrogenada. Revista Ceres, v. 60, n. 3 , p. $363-371,2013$.

LUDWING, R. L. et al. Produção e qualidade do Arachis pintoi. Revista Enciclopédia Biosfera, v. 6 , n. 11 , p. $2-15,2010$.

LINHARES, P. C .F. et al. Teor de matéria seca e composição químico-bromatológica da jitirana (merremia aegyptia 1. urban) em diferentes estádios fenológicos. Revista Verde de Agroecologia e desenvolvimento sustententável, v. 5, n. 3, p. 255 262,2010

MARSHALL, V. M.; LEWIS, M. M.; OSTENDORF, B. Buffel grass (Cenchrus ciliaris) as an invader and threat to biodiversity in arid environments: A review. Journal of Arid Environments, v. 78, s/n., p. 1-12, 2012.

MENDES, M. M. S. et al. Ecophysiology of deciduous plants grown at diferente densities in the semiarid region of Brazil. Theoretical and Experimental Plant Physiology, v. 25, n. 2, p. 94 
$105,2013 a$.

MENDES, M. M. S. et al. Desenvolvimento do milho sob influência de árvores de pau-branco em sistema agrossilvipastoril. Revista Pesquisa Agropecuária Brasileira, v. 48, n. 10, p. 13421350, 2013b.

PEDREIRA, B. C.; PEDREIRA, C. G. S.; LARA, M. A. C. Leaf age, leaf blade portion and light intensity as determinants of leaf phtosynthesis in Panicum maximum Jac. Grassland Science, v. 61, n. 1, p.45-49, 2015.

PEREIRA FILHO, J. M. et al. Disponibilidade de fitomassa do estrato herbáceo de uma Caatinga raleada submetida ao pastejo alternado ovinocaprino. Livestock Research for Rural Development, v. 19, n. 1, p. 1-14, 2007.

FILHO, J. M. P.; SILVA, A. M. A.; CÉZAR, M. F. Manejo da Caatinga para a produção de caprinos e ovinos. Revista Brasileira de Saúde Produção Animal, v. 14, n. 1, p. 77-90, 2013.

RODAL, M. J. N.; SAMPAIO, E. V. S. B.; FIGUEIREDO, M. A. Manual sobre métodos de estudos florísticos e fitossociológicos: ecossistemas Caatinga, 2. ed. Brasília, DF: SB, 2013. 24 p.

RODRIGUES, A. C. et al. Efeito alelopático de folhas de bamburral [Hyptis suaveolens (L.) Poit.] sobre a germinação de sementes de sorgo (Sorghum vulgare Pers.), rabanete (Raphanus sativus L.) e alface (Lactuca sativa L.). Revista Brasileira de Plantas Medicinais, v. 14, n. 3, p. 487-493, 2012.

SANTOS, M. V. F. et al. Potential of Caatinga forage plants in ruminant feeding. Revista Brasileira de Zootecnia, v. 39, sup., p. 204-215, 2010.

SANTOS, R. M. et al. Germinação de sementes de capim-buffel em diferentes temperaturas. Pangeia Cientifica, v. 1, n. 1, p. 11-17, 2013.

SEDDAIU, G. et al. Soil organic matter content and composition as influenced by soil management in a semi-arid Mediterranean agro-silvo-pastoral system. Agriculture, Ecosystems \& Environment, v. 167, n. 1, p. 1-11, 2013.

SILVA, S. C. et al. Sward structural characteristics and herbage accumulation of panicum maximum cv. Mombaça subjected to totational stocking managements. Scientia Agrícola, v. 66, n. 1, p. 819, 2009.
SILVA, P. F. et al. Seasonal patterns of carbon dioxide, water, and energy fluxes over the Caatinga and grassland in the semi-arid region of Brazil. Journal of Arid Environments, v. 147, s/n., p. 112, 2017.

SILVA, J. A. N. et al. Crescimento e produção de espécies forrageiras consorciadas com pinhãomanso. Revista Pesquisa Agropecuária Brasileira, v. 47 , n. 6 , p. 769-775, 2012

SCHACHT, W. H.; MALECHEK, J. C. Nutrition of goats as influenced by thinning and clearing of deciduous woodland in Northeastern Brazil. Journal Animal Science, v. 67, n. 10, p. 2487-2497, 1989.

SMITH, R. G.; GROS, K. L.; ROBERTSON, G. P. Effects of crop diversity on agroecosystem fuction: crop yield response. Revista Ecosystems, v. 11, n. 3, p. 355-366, 2008.

SOIL FERTILITY COMMISSION OF THE STATE OF MINAS GERAIS - SFCST. 1999. Recommendations for the use of correctives and fertilizers in Minas Gerais, 5. ed. Viçosa, MG: UFV, 1999. 359 p.

TURNER N. C. Agronomic options for improving rainfall-use efficiency of crops in dryland farming systems. Journal of Experimental Botany, v. 55, n. 407, p. 2413-2425, 2004

VERSIEUX, L. M. et al. Characterization of the tree componente in a semideciduous forest in the espinhaco range: a subsid y to conservation. Revista Caatinga, v. 24, n. 2, p. 85-94, 2011. 